\title{
Rapid Analysis of Phyical Parameters of Tape Water in Benadir Region, Mogadishu Somalia
}

\author{
Mohamed Ibrahim Abdi-Soojeede ${ }^{1,2, ~ *}$, Feisal Abdullah Salad ${ }^{3}$ \\ ${ }^{1}$ Department of Public Health, Faculty of Health Science, Hope University, Mogadishu, Somalia \\ ${ }^{2}$ Center for Research Development Service, Hope University, Mogadishu, Somali \\ ${ }^{3}$ Department of Clinical Laboratory, Faculty of Health Science, Hope University, Mogadishu, Somalia \\ Email address: \\ drsoojeede@gmail.com (M. I. Abdi-Soojeede), feisalmhsm2015@gmail.com (F. A. Salad) \\ ${ }^{*}$ Corresponding author
}

\section{To cite this article:}

Mohamed Ibrahim Abdi-Soojeede, Feisal Abdullah Salad. Rapid Analysis of Phyical Parameters of Tape Water in Benadir Region, Mogadishu Somalia. International Journal of Natural Resource Ecology and Management. Vol. 5, No. 1, 2020, pp. 31-36. doi: $10.11648 /$ j.ijnrem.20200501.15

Received: February 26, 2020; Accepted: March 9, 2020; Published: March 23, 2020

\begin{abstract}
This study was designed to determine the Physical Parameters of Tap water to evaluate their quality in Benadir region, Mogadishu Somalia, The objective of this study was to investigate the presence of dissolved chemical in tap water in Benadir region. Methods: The study design was used analysis methods with experimental test of tape water in Mogadishu, Somalia. Researchers used rapid detection strips like $\mathrm{pH}$, specific gravity, and the Sample size was 31 out of 35 of target sample, 31 sample is least sample size that can be used. The sample procedure was non probability particularly snow ball. The Result: in table 1, declares sample took was different (some districts took one sample, others with two samples, or three samples and four samples) so they got different percentage, the major sample was 4 and took in Yaqshid district with percentage 12.9\%, also the $\mathrm{pH}$ 5.0 has $35.5 \%$, pH 5.5 has $16.1 \%$ and $\mathrm{pH} 6.0$ has $19.4 \%$, all have lower than the normal ranges, their total percentages was $71 \%$ which means the tape waters in Mogadishu have lower $\mathrm{pH}$ than the normal ranges mentioned by WHO. So that the results in table 2 have $1(3.2 \%)$, was $1.000 \mathrm{SpG}$, which means the one sample took in Wadajir district was normal water, $8(25.8 \%)$ was 1.005 $\mathrm{SpG}$, in eight samples (Yaqshid, Abdiaziz, Kaxda, Hilawaa, Wadajir, and daynile) 13 (41.9\%) was 1.010 SpG, in thirteen samples, $7(22.6 \%)$ was $1.015 \mathrm{SpG}$, in seven samples, 1 (3.2\%), was $1.020 \mathrm{SpG}$, in one sample and last 1 (3.2\%), was $1.025 \mathrm{SpG}$, in one sample. The table 3; shows you that the nitrogen presence in water, the result was 27 (87.1\%) of the samples was Negative nitrogen, and $4(12.9 \%)$ of the samples was positive nitrogen. Conclusion: Water sample from the studied area was not good for drinking because they have low $\mathrm{Ph}$ and also they have high specific Gravity (1.05) Recommendation: Researchers recommend first; to mobilize the community through mass media to educate the harmful effect of water on human health, secondly; the government must establish center for water purification and distribute them to save the lives of the whole community.
\end{abstract}

Keywords: Somalia, Physical Water, Tape Water, Rapid Testing, Benadir Region, Mogadishu

\section{Introduction}

In Somali there is less access to safe drinking water in most parts in Benadir region. Only $45 \%$ of Somalis have access to improved water sources and this increases the prevalence of waterborne diseases. [1]

Subsequently, the total over all Mogadishu's population went back to shallow wells supply for drinking water as mentioned WHO. Consequently risk of epidemics increased considerably because of the poor quality of the sanitary environment and more specifically the contamination of the wells. Starting from 1994, cholera has unfortunately been endemic in Somalia. The last outbreak in December 98 to July 1999 reported more than 10000 cholera cases [2].

There is no Water quality monitoring and house water treatment and safe storages, those are critical interventions to reduce the contamination of water. This study was designed to determine the Physiochemical Parameters of Tap water to evaluate their quality in Benadir region, Mogadishu Somalia, The objective of this study was to investigate the presence of dissolved chemical in tap water in Benadir region. 


\section{Backgrounds}

Before the collapse of ex- Presidents Mohamed siyad the system of Water for Mogadishu was harvested from the well field of Afgoi (Ceelasha), about $18 \mathrm{~km}$ north-west of the town, and from the well field of Balcad, located about $17 \mathrm{~km}$ to the north-east. [3].

The Balcad well fields after that were closed down at the end of 1992 due to the poor condition, this time there is no governmental authority repairing it, and the country was in civil war. The Afgoi well fields were operational until mid1995, as Mentioned ICRC. Of the 32 boreholes only two have collapsed. Presently 14 are, in principle, fully operational, the others need pumps and other equipment in 1997. [4]

Later on, it was supposed hand dig wells to use as domestic water distributed by Private Owners Companies, those facilities to cover the water needs of each districts, but there is no survey to detect the parasites of the water used as drinking water for whole communities in Mogadishu Somalia. As mentioned by Libessart, Y. et all (2000), the entire Mogadishu's population went back to shallow wells supply for drinking water and cleaning purposes. That exist some districts still using shallow wells for their tape water. $[4,5]$

This article was attempt to discover the physiochemical within water that can possible cause acute and chronic illness to the susceptible persons (children and olders), also took randomly samples from some of wells used in each districts as tape water or drinking, while some people can be used Distilled water as drink water, but most of the communities in Mogadishu are used to tape water as cooking and drink water.

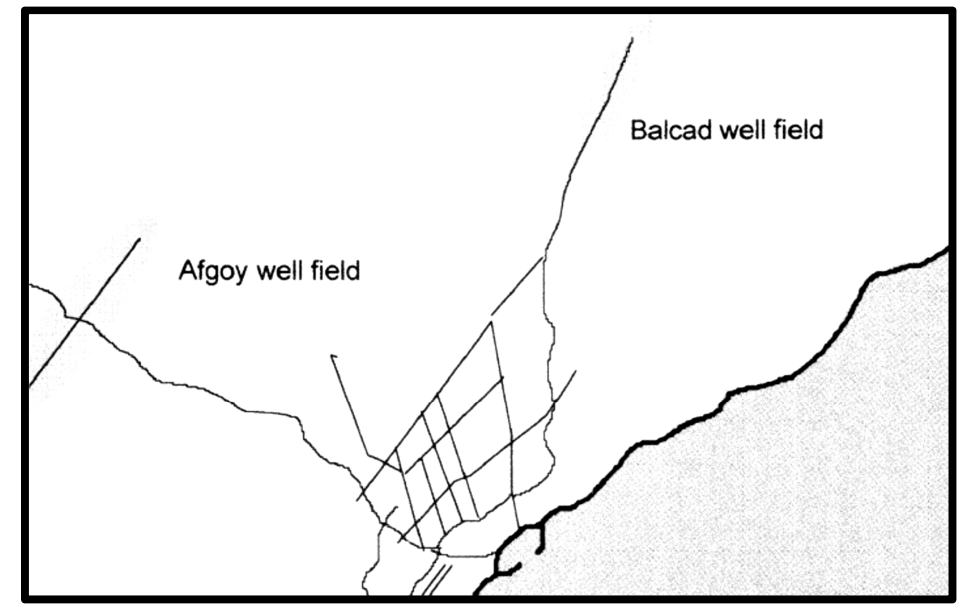

Figure 1. Van der Plas, M. et al (2013). [5].

\section{Literature Review}

\subsection{PH of Water}

The $\mathrm{pH}$ of water is a measure of the acid-base balance and, In mostly the normal value of drinking water is neutral 7.0 , in most natural waters, is controlled by the carbon dioxide-bicarbonate-carbonate equilibrium system, but in others water like by human sewage and industrial effluent is control by many different chemicals and biological substances. [6]. The Rahmanian, N et al (2015) in Malaysia, found that the $\mathrm{pH}$ values of water samples was in the range between 7.01 and 8.21, where the lowest and highest values are from samples 5 (Taman Maju (TM)), [7].

In Health effect the $\mathrm{pH}$ usually has no direct impact on water consumers, but High $\mathrm{PH}$ or Low PH mentioned by WHO 2007 Guideline, Strong concentrated acids or alkalis are corrosive, whereas dilute and weak acids and alkalis are not corrosive.

Sofi, M. H., et al (2014), they found after tested two Mice with Nonobese diabetic with acidic PH water and Natural water they got, Female NOD mice that were maintained on acidic $\mathrm{pH}$ water (AW) developed insulitis and hyperglycemia rapidly compared with those on neutral $\mathrm{pH}$ water $(\mathrm{NW})$. so the acidic $\mathrm{PH}$ of drinking water can influence increase severity of Diabetics patients. [8].

Also that is relationship between $\mathrm{PH}$ of drinking water and cognitive impairment of elders as epidemiological study done by Jacqmin, H. et al (1994) they found When the four variables (calcium, aluminum, $\mathrm{pH}$, and aluminum $\times \mathrm{pH}$ interaction) were considered in the statistical analysis as a group, this group was significantly related to cognitive impairment $(p=0.01)$. [9]

\subsection{Specific Gravity of Water}

The specific gravity ("Sp.G.") is common measurement standard tools used to measure the of solids, gases and Liquids. So the specific gravity of a liquid states you how much more or less dense the liquid is than water. Water has a specific gravity of 1.000 (at temperature near $4^{\circ} \mathrm{C}$ ) which is the standard measurement of pure water. If a liquid is denser than pure water, then its specific gravity will greater than 1 . If it is less dense than pure water, then the specific gravity is less than 1. [10].

The researcher seemed too good, to determine the specific of tape water to know the density of that water when compared to pure water at temperature near $4^{\circ} \mathrm{C}$. so that it is not standard when looking for water testing procedure, but it is the theory of researcher to add this measurement for testing water purity. 


\subsection{Nitrogen in Water}

The guidelines for drinking water quality wrote by who (2017), mentioned that there is association of nitrate intake with primarily gastric cancers. But not know actual amount of nitrate to cause the gastric cancers. Also suggests that exposure to nitrate in drinking-water may alter human thyroid gland function by competitively inhibiting thyroidal iodide uptake, leading to altered thyroid hormone concentrations and functions. [11, 12].

Presence of Nitrogen in small quantity is good and have not influence the health, but in large quantity of nitrogen in drinking water cause many problem to public health. As the normal value mentioned by Environmental Protection Agency (EPA) $10 \mathrm{mg} / \mathrm{L}$ standard as the maximum contaminant level (MCL) for nitrate-nitrogen and $1 \mathrm{mg} / \mathrm{L}$ for nitrite-nitrogen for regulated public water systems. [13]

\section{Methods}

\subsection{Study Design}

The study design was used analysis methods with experimental test of tape water in Mogadishu, Somalia. Researchers used rapid detection strips like $\mathrm{pH}$, specific gravity, nitrogen because this was simple and available methods that we can examine the tape water.

\subsection{Study Area}

The study area was all districts of benadir region, not directly contacted the community but the researchers took samples of tape water $(300 \mathrm{ml})$ from the districts in Mogadishu, also there was districts took more than two to three samples for reason of availabilities. Sample size was 31 out of 35 of target sample, 31 sample is least sample size that can be used. The sample procedure was non probability particularly snow ball, because the circumstance had caused not to get full samples.

\subsection{Materials Used to Water Testing}

The materials used was simple matters like $\mathrm{Ph}$ meter, urine strips testing for both specific gravity and Nitrogen of tape water, because researcher not have available tools for water testing, there is not existing data about the water testing and so on, researcher tried to used simple materials which was available and good to estimate the general quality of water.

\subsection{Data Analysis}

The data was analysed by using SPSS version 16.0, descriptive statistics was presented using tables. And also presented their significant $\mathrm{P}$ value, to know if it was acceptable or not.

\section{Results of the Study}

The result was focused on three sections, first section was presented frequency of samples on districts, the second section was consists of three frequency tables, to present the percentage difference of $\mathrm{PH}$, specific gravity and Nitrogen. And lasts section was descriptive statistics and significance $\mathrm{P}$ value.

Table 1. Cross tabulation of Districts \& PH of tape water samples.

\begin{tabular}{|c|c|c|c|c|c|c|c|}
\hline \multicolumn{8}{|c|}{ Districts * PH of water Cross tabulation } \\
\hline \multirow{2}{*}{ Districts } & \multicolumn{6}{|c|}{ PH of water } & \multirow{2}{*}{ Total } \\
\hline & 5.0 & 5.5 & 6.0 & 6.5 & 7.0 & Interpretation & \\
\hline Howlwadaag & $3(9.7 \%)$ & $0(0.0 \%)$ & $0(0.0 \%)$ & $0(0.0 \%)$ & $0(0.0 \%)$ & $\mathrm{pH}=\mathrm{A}$ & \\
\hline Hodon & $2(6.5 \%)$ & $0(0.0 \%)$ & $1(3.2 \%)$ & $0(0.0 \%)$ & $0(0.0 \%)$ & $\mathrm{pH}=\mathrm{A}$ & $3(9.7 \%) \mathrm{p}$ \\
\hline Yaqshid & $0(0.0 \%)$ & $2(6.4 \%)$ & $2(6.4 \%)$ & $0(0.0 \%)$ & $0(0.0 \%)$ & $\mathrm{pH}=\mathrm{A}$ & $4(12.9 \%)$ \\
\hline Abdiaziz & $1(3.2 \%)$ & $0(0.0 \%)$ & $0(0.0 \%)$ & $0(0.0 \%)$ & $0(0.0 \%)$ & $\mathrm{pH}=\mathrm{A}$ & $1(3.2 \%)$ \\
\hline Kaxda & $0(0.0 \%)$ & $1(3.2 \%)$ & $0(0.0 \%)$ & $1(3.2 \%)$ & $0(0.0 \%)$ & $\mathrm{pH}=\mathrm{A}$ & $2(6.5 \%)$ \\
\hline Hamar Jajab & $1(3.2 \%)$ & $1(3.2 \%)$ & $0(0.0 \%)$ & $1(3.2 \%)$ & $0(0.0 \%)$ & $\mathrm{pH}=\mathrm{A}$ & $3(9.7 \%)$ \\
\hline Wadajir & $0(0.0 \%)$ & $1(3.2 \%)$ & $1(3.2 \%)$ & $1(3.2 \%)$ & $0(0.0 \%)$ & $\mathrm{pH}=\mathrm{A}$ & $3(9.7 \%)$ \\
\hline Wardhigley & $1(3.2 \%)$ & $0(0.0 \%)$ & $0(0.0 \%)$ & $0(0.0 \%)$ & $0(0.0 \%)$ & $\mathrm{pH}=\mathrm{A}$ & $1(3.2 \%)$ \\
\hline Dharkeynley & $0(0.0 \%)$ & $0(0.0 \%)$ & $1(3.2 \%)$ & $1(3.2 \%)$ & $1(3.2 \%)$ & $\mathrm{pH}=2 \mathrm{~A} \& 1 \mathrm{~N}$ & $3(9.7 \%)$ \\
\hline Shibis & $1(3.2 \%)$ & $0(0.0 \%)$ & $0(0.0 \%)$ & $0(0.0 \%)$ & $0(0.0 \%)$ & $\mathrm{pH}=\mathrm{A}$ & $1(3.2 \%)$ \\
\hline Shangani & $0(0.0 \%)$ & $0(0.0 \%)$ & $0(0.0 \%)$ & $0(0.0 \%)$ & $1(3.2 \%)$ & $\mathrm{pH}=\mathrm{N}$ & $1(3.2 \%)$ \\
\hline Hiliwaa & $0(0.0 \%)$ & $0(0.0 \%)$ & $0(0.0 \%)$ & $1(3.2 \%)$ & $0(0.0 \%)$ & $\mathrm{pH}=\mathrm{A}$ & $1(3.2 \%)$ \\
\hline Daynile & $0(0.0 \%)$ & $0(0.0 \%)$ & $1(3.2 \%)$ & $1(3.2 \%)$ & $0(0.0 \%)$ & $\mathrm{pH}=\mathrm{A}$ & $2(6.5 \%)$ \\
\hline Boondhere & $1(3.2 \%)$ & $0(0.0 \%)$ & $0(0.0 \%)$ & $0(0.0 \%)$ & $0(0.0 \%)$ & $\mathrm{pH}=\mathrm{A}$ & $1(3.2 \%)$ \\
\hline Waaberi & $1(3.2 \%)$ & $0(0.0 \%)$ & $0(0.0 \%)$ & $1(3.2 \%)$ & $0(0.0 \%)$ & $\mathrm{pH}=\mathrm{A}$ & $2(6.5 \%)$ \\
\hline Total & $11(35.5 \%)$ & $5(16.1 \%)$ & $6(19.4 \%)$ & $7(22.6 \%)$ & $2(6.5 \%)$ & $(95.1 \%) \mathrm{A},(4.9 \%) \mathrm{N}$ & $31(100 \%)$ \\
\hline
\end{tabular}

$\mathrm{NB}$ : the abbreviation of $\mathrm{pH}=$ power of hydrogen, $\mathrm{A}=$ acidic water, $\mathrm{N}=$ Neutral water.

Source: Primary data

The above table 1, declares sample took was different (some districts took one sample, others with two samples, or three samples and four samples) so they got different percentage, the major sample was 4 and took in yaqshid district with percentage $12.9 \%$, the second groups was took 3 samples with percentage
9.7\% $(9.7 \% * 5)$ in five districts (like Howlwadaag, Hodon, Hamarjajab, Wadajir and dharkeynley districts) their total percentages was $48.5 \%$ of the total percentages. The third parts was took 2 samples of tape water was collected with percentage $6.5 \%(6.5 \% * 3)$ in three districts (like kaxda, Daynile and 
waaberi distircts) their total percentages was $19.5 \%$ of the total percentages. The fourth parts was took 1 sample was collected with percentages $3.2 \%(3.2 \% * 6)$ in six districts like (Abdiaziz, Wardhigley, Shibis, Shagani, Hiliwaa and boondheere) their total percentages was $19.2 \%$ of the total percentages.

The PH (power of hydrogen), is assigned as one of the essential water quality parameters used for water testing. Measurement of $\mathrm{pH}$ as common way relates to the water acidity or alkalinity. So the sample is considered to be ranked between "1-14", as separation the acid will have the $\mathrm{pH}$ is below 7.0. In the meantime, it is alkaline will have the $\mathrm{pH}$ is higher than 7.0, and 7.0, will be the neutral.

The $\mathrm{pH}$ of the tape water samples was between (5.0 up to 7.0), as know the WHO guidelines presented the normal drinking water $\mathrm{pH}$ ranges in between 6.5 and 8.5 (Table 2), the $\mathrm{pH} 5.0$ has $35.5 \%, \mathrm{pH} 5.5$ has $16.1 \%$ and $\mathrm{pH} 6.0$ has $19.4 \%$, all have lower than the normal ranges, their total percentages was $71 \%$ of the total percentages, that means $71 \%$ of tape water in Mogadishu has lower $\mathrm{pH}$ than the normal ranges mentioned by WHO.

Table 2. Cross tabulation of Districts \& Specific Gravity.

\begin{tabular}{|c|c|c|c|c|c|c|c|c|}
\hline \multicolumn{9}{|c|}{ Districts * Specific Gravity Cross tabulation } \\
\hline \multirow{2}{*}{\multicolumn{2}{|c|}{ Districts }} & \multicolumn{6}{|c|}{ Specific Gravity } & \multirow{2}{*}{ Total } \\
\hline & & 1.000 & 1.005 & 1.010 & 1.015 & 1.020 & 1.025 & \\
\hline & Howlwadaag & $0(0.0 \%)$ & $0(0.0 \%)$ & $1(3.2 \%)$ & $1(3.2 \%)$ & $0(0.0 \%)$ & $1(3.2 \%)$ & $3(9.7 \%)$ \\
\hline & Hodon & $0(0.0 \%)$ & $0(0.0 \%)$ & $0(0.0 \%)$ & $2(6.5 \%)$ & $1(3.2 \%)$ & $0(0.0 \%)$ & $3(9.7 \%)$ \\
\hline & Yaqshid & $0(0.0 \%)$ & $2(6.5 \%)$ & $1(3.2 \%)$ & $1(3.2 \%)$ & $0(0.0 \%)$ & $0(0.0 \%)$ & $4(12.9 \%)$ \\
\hline & Abdiaziz & $0(0.0 \%)$ & $1(3.2 \%)$ & $0(0.0 \%)$ & $0(0.0 \%)$ & $0(0.0 \%)$ & $0(0.0 \%)$ & $1(3.2 \%)$ \\
\hline & Kaxda & $0(0.0 \%)$ & $1(3.2 \%)$ & $1(3.2 \%)$ & $0(0.0 \%)$ & $0(0.0 \%)$ & $0(0.0 \%)$ & $2(6.5 \%)$ \\
\hline & Wadajir & $1(3.2 \%)$ & $1(3.2 \%)$ & $1(3.2 \%)$ & $0(0.0 \%)$ & $0(0.0 \%)$ & $0(0.0 \%)$ & $3(9.7 \%)$ \\
\hline & Wardhigley & $0(0.0 \%)$ & $0(0.0 \%)$ & $1(3.2 \%)$ & $0(0.0 \%)$ & $0(0.0 \%)$ & $0(0.0 \%)$ & $1(3.2 \%)$ \\
\hline & Dharkeynley & $0(0.0 \%)$ & $0(0.0 \%)$ & $3(9.7 \%)$ & $0(0.0 \%)$ & $0(0.0 \%)$ & $0(0.0 \%)$ & $3(9.7 \%)$ \\
\hline & Shibis & $0(0.0 \%)$ & $0(0.0 \%)$ & $0(0.0 \%)$ & $1(3.2 \%)$ & $0(0.0 \%)$ & $0(0.0 \%)$ & $1(3.2 \%)$ \\
\hline & Shangani & $0(0.0 \%)$ & $0(0.0 \%)$ & $1(3.2 \%)$ & $0(0.0 \%)$ & $0(0.0 \%)$ & $0(0.0 \%)$ & $1(3.2 \%)$ \\
\hline & Hiliwaa & $0(0.0 \%)$ & $1(3.2 \%)$ & $0(0.0 \%)$ & $0(0.0 \%)$ & $0(0.0 \%)$ & $0(0.0 \%)$ & $1(3.2 \%)$ \\
\hline & Daynile & $0(0.0 \%)$ & $2(6.5 \%)$ & $0(0.0 \%)$ & $0(0.0 \%)$ & $0(0.0 \%)$ & $0(0.0 \%)$ & $2(6.5 \%)$ \\
\hline & Waaberi & $0(0.0 \%)$ & $0(0.0 \%)$ & $2(6.5 \%)$ & $0(0.0 \%)$ & $0(0.0 \%)$ & $0(0.0 \%)$ & $2(6.5 \%)$ \\
\hline \multicolumn{2}{|l|}{ Total } & $1(3.2 \%)$ & $8(25.7 \%)$ & $13(41.9)$ & $7(22.5 \%)$ & $1(3.2 \%)$ & $1(3.2 \%)$ & $31(100 \%)$ \\
\hline
\end{tabular}

Source: Primary data

The table 2 above, presented the specific gravity of tape water samples that collected in different district in Mogadishu Somalia, as you we know the specific gravity also known as relative density is the ratio of density of water to the density of a reference substance. So pure water with no salts has 1.000 , and Sea-water has specific gravity $1.025-1.030$, and there are many other water like tape water, shallow wells water and pond water have specific gravity between $1.05-1.020$.
(Reference Chester K. wentworth 1939). So that the results in table 2 have $1(3.2 \%)$, was $1.000 \mathrm{SpG}$, which means the one sample took in Wadajir district was normal water, 8 (25.8\%) was $1.005 \mathrm{SpG}$, in eight samples (yaqshid, abdiaziz, Kaxda, Hilawaa, Wadajir, and daynile) $13(41.9 \%)$ was $1.010 \mathrm{SpG}$, in thirteen samples, 7 (22.6\%) was $1.015 \mathrm{SpG}$, in seven samples, $1(3.2 \%)$, was $1.020 \mathrm{SpG}$, in one sample and last $1(3.2 \%)$, was $1.025 \mathrm{SpG}$, in one sample.

Table 3. Cross tabulation of Districts and Nitrogen level in tape water samples.

\begin{tabular}{|c|c|c|c|c|}
\hline \multicolumn{5}{|c|}{ Districts * Nitrogen level Cross tabulation } \\
\hline & & \multicolumn{2}{|c|}{ Nitrogen level } & \multirow{2}{*}{ Total } \\
\hline & & Negative & Positive & \\
\hline \multirow{15}{*}{ Districts } & Howlwadaag & $1(3.2 \%)$ & $2(6.5 \%)$ & $3(9.7 \%)$ \\
\hline & Hodon & $3(9.7 \%)$ & $0(0.0 \%)$ & $3(9.7 \%)$ \\
\hline & Yaqshid & $44(12.9 \%)$ & $0(0.0 \%)$ & $4(12.9 \%)$ \\
\hline & Abdiaziz & $1(3.2 \%)$ & $0(0.0 \%)$ & $1(3.2 \%)$ \\
\hline & Kaxda & $2(6.5 \%)$ & $0(0.0 \%)$ & $2(6.5 \%)$ \\
\hline & Hamar Jajab & $3(9.7 \%)$ & $0(0.0 \%)$ & $3(9.7 \%)$ \\
\hline & Wadajir & $3(9.7 \%)$ & $0(0.0 \%)$ & $3(9.7 \%)$ \\
\hline & Wardhigley & $1(3.2 \%)$ & $0(0.0 \%)$ & $1(3.2 \%)$ \\
\hline & Dharkeynley & $3(9.7 \%)$ & $0(0.0 \%)$ & $3(9.7 \%)$ \\
\hline & Shibis & $1(3.2 \%)$ & $0(0.0 \%)$ & $1(3.2 \%)$ \\
\hline & Shangani & $0(0.0 \%)$ & $1(3.2 \%)$ & $1(3.2 \%)$ \\
\hline & Hiliwaa & $1(3.2 \%)$ & $0(0.0 \%)$ & $1(3.2 \%)$ \\
\hline & Daynile & $2(6.5 \%)$ & $0(0.0 \%)$ & $2(6.5 \%)$ \\
\hline & Boondhere & $1(3.2 \%)$ & $0(0.0 \%)$ & $1(3.2 \%)$ \\
\hline & Waaberi & $1(3.2 \%)$ & $1(3.2 \%)$ & $2(6.5 \%)$ \\
\hline Total & & $27(87.1 \%)$ & $4(12.9 \%)$ & $31(100 \%)$ \\
\hline
\end{tabular}

Source: Primary data 
The table 3; shows you that the nitrogen is mostly sign of high nutrient in water, so $27(87.1 \%)$ of the samples was Negative nitrogen, and $4(12.9 \%)$ of the samples was positive nitrogen. So that means the tape water samples was mostly negative with percentages $27(87.1 \%)$. As we know WHO guideline of drinking water nitrogen

Table 4. Significance $P$ value.

\begin{tabular}{|c|c|c|c|c|c|c|}
\hline \multicolumn{7}{|l|}{ One-Sample Test } \\
\hline & \multicolumn{6}{|c|}{ Test Value $=3$} \\
\hline & \multirow{2}{*}{$\mathbf{T}$} & \multirow{2}{*}{ Df } & \multirow{2}{*}{ Sig. (2-tailed) } & \multirow{2}{*}{ Mean Difference } & \multicolumn{2}{|c|}{ 95\% Confidence Interval of the Difference } \\
\hline & & & & & Lower & Upper \\
\hline Districts & 4.783 & 30 & .000 & 4.290 & 2.46 & 6.12 \\
\hline $\mathrm{PH}$ of water & -2.108 & 30 & .043 & -.516 & -1.02 & -.02 \\
\hline Specific Gravity & .349 & 30 & .730 & .065 & -.31 & .44 \\
\hline Nitrogen level & -30.569 & 30 & .000 & -1.871 & -2.00 & -1.75 \\
\hline
\end{tabular}

Source: primary data

This Table 4 presented you significant $\mathrm{P}$ value of the data in SPSS one-Sample test. Researcher had test value 3, so the result had significant $\mathrm{P}$ value or Sig. (2-tailed) $=0.000$ which means the test is significant, because the used the rule was, If $\mathrm{P}>0.05$ the test is not significant (the sample is not significantly different than $\mu=3$ ). In last, the analysis of the of sample test showed that the dominant answer of that questions are significance no difference at all except Specific gravity have significance $\mathrm{P}$ value $=0.730$, which indicates that there are difference in specific gravity.

\section{Discussion}

The study was presented to determine the Physical Parameters ( $\mathrm{PH}$, Specific Gravity, and Nitrogen test), of Tap water to evaluate their quality in Benadir region, Mogadishu Somalia, the table 1: Cross tabulation of Districts and $\mathrm{PH}$ of water, was consists of levels of $\mathrm{PH}$ tested tape waters in all districts of benadir Regions, the highest rank of $\mathrm{PH}$ was $95.1 \%$ was acidic water which means the water $\mathrm{PH}$.

The physical properties of tape water sample that were collected different districts in benadir region, Mogadishu Somalia, researchers made the following conclusion. Water sample from the studied area was not good for drinking because they have low $\mathrm{Ph}$ then normal and also they have high specific Gravity (1.05) then normal (1.0) which indicates there a lot of chemical dissolved with in it, some sample have $1.20 \mathrm{Sp}$, which was near the specific Gravity of sea water, As we known Mogadishu is located in Indian oceans. Finally water samples was very less or low level to get nitrogen within that is good points. Water samples were detected that there was very clear in appearance they have not any turbidity and floating matters, in odder they was good, but some has turbid like odors, but test was hard, salty and normal like water. [14]

\section{Conclusion}

This study was focus on testing tape waters on benadir regions Mogadishu Somalia, the general objective of this research was to determine Physical Parameters of Tap water to evaluate their quality. The research methods that researchers used was analysis methods with experimental test of tape water. Researchers used rapid detection strips like $\mathrm{pH}$, specific gravity, and the Sample size was 31 out of 35 of target sample. The results was $\mathrm{PH}$ tested tape waters in all districts of benadir Regions, the highest rank of $\mathrm{PH}$ was $95.1 \%$ was acidic water, they have high specific Gravity (1.05) then normal (1.0) and low level to get nitrogen.

\section{Recommendation}

Researchers recommend first; to mobilize the community through mass media to educate the harmful effect of water on human health, secondly; the government must establish center for water purification and distribute them to save the lives of the whole community. Thirdly; the government must make continuous monitoring of ground water for their physical and chemical properties. Fourthly: Private companies working with water distribution must use large filters to simplify the density of water and lesser their contamination.

\section{Acknowledgements}

The researchers would express their thanks to the president of all campus on Hope University, Prof: Najib Abdulkarim, and Academic Dean of Mogadishu campus Mr. Abdurahman Sheikh Mohamud, and Classes of Public health like Class K, L, M and N, especially the Class Masters of Class N and M. we appreciated for their participation. Lastly acknowledge our Dear friend Mr. Muhidin khalif Abdi, Who has helped us to the materials.

\section{References}

[1] UNICEF (2015), Priority issues; https://www.unicef.org/somalia/wes_95.html

[2] FAO (2006); Health Systems Profile- Somalia, Regional Health Systems Observatory- EMRO,

https://apps.who.int/medicinedocs/documents/s17309e/s17309 e.pdf 
[3] World Bank. 1985. Somalia - Mogadishu Water Supply Project (English). Washington, DC: World Bank. http://documents.worldbank.org/curated/en/575511468303086 894/Somalia-Mogadishu-Water-Supply-Project

[4] Libessart, Y., \& Hamache, Y. (2000, November). Integrated chlorination campaign in Mogadishu. In WEDC CONFERENCE (Vol. 26, pp. 237-239).

[5] van der Plas, M., \& Nembrini, P. G. (2013). In a state of uncertainty? Mogadishu water supply.

[6] WHO (2007); pH in Drinking-water; Revised background document for development of WHO Guidelines for Drinkingwater Quality;

https://www.who.int/water_sanitation_health/dwq/chemicals/p h_revised_2007_clean_version.pdf

[7] Rahmanian, N., Ali, S. H. B., Homayoonfard, M., Ali, N. J., Rehan, M., Sadef, Y., \& Nizami, A. S. (2015). Analysis of physiochemical parameters to evaluate the drinking water quality in the State of Perak, Malaysia. Journal of Chemistry, 2015.

[8] Sofi, M. H., Gudi, R., Karumuthil-Melethil, S., Perez, N., Johnson, B. M., \& Vasu, C. (2014). pH of drinking water influences the composition of gut microbiome and type 1 diabetes incidence. Diabetes, 63 (2), 632-644.
[9] Jacqmin, H., Commenges, D., Letenneur, L., BarbergerGateau, P., \& Dartigues, J. F. (1994). Components of drinking water and risk of cognitive impairment in the elderly. American journal of epidemiology, 139 (1), 48-57.

[10] University of Illinois at Urbana-Champaign, Department of Physics; (2007) what is specific gravity of water, https://van.physics.illinois.edu/qa/listing.php?id=5454,

[11] World Health Organisation (WHO), \& World Health Organisation Staff. (2004). Guidelines for drinking-water quality (Vol. 1). World Health Organization.

[12] Cotruvo, J. A. (2017). 2017 WHO guidelines for drinking water quality: first addendum to the fourth edition. Journal American Water Works Association, 109 (7), 44-51.

[13] US EPA, "Basic Information on Nitrate in Drinking Water," and "Basic Information on Nitrite in Drinking Water," http://water.epa.gov/drink/contaminants/basicinformation/nitr ate.cfm. and http://water.epa.gov/drink/contaminants/basicinformation/nitri te.cfm.

[14] Abdi-Soojeede, M. I. and Kullane, M. A. (2019) Study of Community Perception on Drinking Water Quality in Mogadishu, Somalia. Open Journal of Applied Sciences, 9, 361-371. https://doi.org/10.4236/ojapps.2019.95030 